ONLINE MUTATION REPORT

\title{
RYR1 mutations in UK central core disease patients: more than just the C-terminal transmembrane region of the RYR 1 gene
}

\author{
S Shepherd, F Ellis, J Halsall, P Hopkins, R Robinson
}

J Med Genet 2004;41:e33 (http://www.jmedgenet.com/cgi/content/full/41/3/e33). doi: 10.1136/jmg.2003.014274

$\mathrm{T}$ he congenital myopathies are a group of disorders that are difficult to distinguish. Diagnosis is frequently dependent on the result of histological examination of muscle biopsy specimens in conjunction with clinical diagnosis. There is a significant degree of overlap in the clinical features of different congenital myopathies: identification of genetic determinants may therefore aid in establishing a firm diagnosis.

Central core disease (CCD) is a rare congenital myopathy. Histologically, using oxidative enzyme stains, it is identified by the abundance of central cores, characterised by localised areas of mitochondrial depletion and sarcomere disorganization exclusively in type 1 skeletal muscle fibres, and extending throughout their length. Cores are often central and unique, but may be eccentric or multiple within one fibre. Affected patients may present with congenital muscle hypotonia, pronounced proximal weakness, delayed motor development, and slightly elevated creatine kinase (CK) levels. In addition, skeletal anomalies such as congenital hip displacement and scoliosis are frequent. Later in life muscle strength may improve, but in rare cases progressive muscle weakness is observed. Respiratory insufficiency is rare. ${ }^{12}$ Overall, the disorder demonstrates significant phenotypic variability; in a study of 13 cases, as many as $40 \%$ of patients with histological signs of disease were clinically asymptomatic. ${ }^{3}$

CCD is predominantly reported as an autosomal dominant trait. However, there is evidence that inheritance may be autosomal recessive in some families, ${ }^{45}$ and sporadic cases have been documented. ${ }^{67}$ It is recognised as the primary disorder associated and allelic with the pharmacogenetic disorder malignant hyperthermia $(\mathrm{MH}){ }^{8}$ However, characteristic muscle cores have been reported in association with several other myopathies, namely multi-mini core disease $(\mathrm{MmD})$, nemaline myopathy, and hypertrophic cardiomyopathy. All have additional definitive characteristics in their own right, although in some cases the phenotypic boundaries are difficult to assert.

$\mathrm{MH}$ also shows autosomal dominant inheritance, and is genetically heterogeneous with six susceptibility loci identified to date. ${ }^{10} \mathrm{MH}$ reactions are triggered in susceptible individuals following exposure to certain anaesthetic agents. Crises reflect a disturbance of skeletal muscle calcium homeostasis. Uncontrolled sarcoplasmic reticulum calcium release involving the ryanodine receptor (RYRl) results in sustained muscle contraction, elevated temperature, and metabolic acidosis, and may be fatal if not treated. ${ }^{11}{ }^{12}$ Clinically, MH status may be assessed by exposure in the laboratory of a patient's muscle biopsy specimen to incremental doses of specific trigger agents (caffeine, halothane) and measuring the in vitro contracture response using the contracture test (IVCT). ${ }^{13}{ }^{14}$ Alternatively, in families where MH status has been confirmed by a positive IVCT in the

\section{Key points}

- Central core disease (CCD) is predominantly an autosomal dominant neuromuscular condition exhibiting variable penetrance, which also has been described in association with the pharmacogenetic disorder malignant hyperthermia (MH).

- In many cases of CCD, mutations in RYRI have been detected, resulting in defective calcium handling of the skeletal muscle ryanodine receptor.

- CCD and MH status have been characterised in 21 investigated families, with RYR1 mutations in $57 \%$ of cases. Results suggest that regions other than the Cterminus of the RYRl gene have important roles in CCD pathogenesis, and that certain RYR1 mutations may be specific to CCD presenting with or without predisposition to $\mathrm{MH}$.

- These data may aid in the diagnosis of $\mathrm{CCD} / \mathrm{MH}$ in the future.

family index case, identification of an RYRl mutation proven causative of MH may be used for diagnosis. ${ }^{15}$

CCD patients may or may not be susceptible to $\mathrm{MH}$, with phenotypic variability with respect to MH status sometimes observed within the same pedigree. ${ }^{16}{ }^{17}$ One explanation is the independent segregation of genetic determinants of CCD and $\mathrm{MH}$ within a family. Alternatively, variability could reflect patient age at the time of muscle biopsy and/or the mildly progressive nature of CCD documented in some individuals. ${ }^{18}$ Reports that histological examination of muscle specimen cross sections (rather than longitudinal sections) does not enable differentiation between CCD and MmD, indicates that the method of specimen analysis is also important for the accurate characterisation of these disorders. ${ }^{19}$ All CCD patients should be considered at risk for $\mathrm{MH}$ unless diagnosed as $\mathrm{MH}$ normal on muscle biopsy testing. However, in some individuals, a positive muscle biopsy test result may be a consequence of the underlying muscle pathology rather than $\mathrm{MH}$ susceptibility (MHS) itself. Patients with other muscular disorders unrelated to $\mathrm{MH}$, and who are considered an anaesthetic risk, have been known to test positive with the IVCT. ${ }^{20}$

Abbreviations: $C C D$, central core disease; $C K$, creatine kinase; $M H(S)$, malignant hyperthermia (susceptibility); $\mathrm{MmD}$, multi mini-core disease; IVCT, in vitro contracture test; EC, excitation contraction 
Table 1 Clinical details of probands investigated

\begin{tabular}{|c|c|c|c|c|c|c|c|c|c|c|c|}
\hline \multirow[b]{2}{*}{$\begin{array}{l}\text { Family } \\
\text { (LMH) }\end{array}$} & \multirow[b]{2}{*}{$\begin{array}{l}\text { Age in } \\
\text { years at } \\
\text { biopsy }\end{array}$} & \multirow[b]{2}{*}{ Gender } & \multirow[b]{2}{*}{ History } & \multirow[b]{2}{*}{ Histology } & \multirow[b]{2}{*}{$\begin{array}{l}\text { Clinical features } \\
\text { of neuromuscular } \\
\text { disorders }\end{array}$} & \multirow{2}{*}{$\begin{array}{l}\text { CK IU/I } \\
\text { At time } \\
\text { of MH } \\
\text { biopsy }\end{array}$} & \multicolumn{4}{|c|}{ IVCT dataß } & \multirow[b]{2}{*}{$\begin{array}{l}\text { MH } \\
\text { status }\end{array}$} \\
\hline & & & & & & & $\begin{array}{l}\mathrm{H} \\
\text { thr } \\
\%\end{array}$ & $\begin{array}{l}\text { H } \\
\text { contr } \\
\text { g }\end{array}$ & $\begin{array}{l}\mathrm{C} \\
\text { thr } \\
\mathrm{mM}\end{array}$ & $\begin{array}{l}\text { C } \\
\text { contr } \\
\text { g }\end{array}$ & \\
\hline 31 & 37 & $\mathrm{~F}$ & $C C D$ referral & $C C D$ & $\begin{array}{l}\text { No cramps. } \\
\text { Numbness and } \\
\text { weakness in limbs }\end{array}$ & 70 & $2.0 B^{* *}$ & 2.8 & $<8^{* *}$ & 0 & $M H S^{* *}$ \\
\hline 32 & 24 & $\mathrm{~F}$ & $\begin{array}{l}\text { Relatives had } \mathrm{MH} \\
\text { reactions. } \\
\text { Postoperative CK } \\
18000 \text {, temp. } 39.9^{\circ} \mathrm{C} \text {, } \\
\text { myoglobinuria }\end{array}$ & Cores present. & Some cramps in legs & 1000 & 0.5 & 0.6 & - & - & MHS \\
\hline 33 & 24 & M & $\begin{array}{l}\text { Poor muscle } \\
\text { development, } \\
\text { congenital dislocating } \\
\text { hips (CDH) Twice, } \\
\text { muscle rigidity after } \\
\text { suxamethonium, once } \\
\text { with cyanosis and } \\
\text { temp. } 43^{\circ} \mathrm{C}\end{array}$ & $\begin{array}{l}C C D \text { with } \\
\text { dystrophic } \\
\text { changes }\end{array}$ & Scoliosis. No cramps & 1419 & 0.5 & 4.3 & 1 & 0.4 & MHS \\
\hline $34(1 \mathrm{P})$ & 11 & $\mathrm{~F}$ & Known case of CCD & $C C D$ & Scoliosis. Weak legs & 35 & 0.5 & 1.1 & 0.5 & 1.55 & MHS \\
\hline $34(2 P)$ & 32,37 & $\mathrm{~F}$ & Known case of CCD. & $\begin{array}{l}C C D \text { and } \\
\text { nemaline rods }\end{array}$ & Weak legs & 44 & 2 & 0.2 & 2 & 0.2 & MHS \\
\hline 36 & 28 & $\mathrm{~F}$ & $C C D$ referral & $C C D$ & $\begin{array}{l}\text { Limb weakness. } \\
\text { Scoliosis }\end{array}$ & 131 & $>2$ & 0.05 & 2 & 0.75 & MHE \\
\hline 37 & 25 & $\mathrm{~F}$ & $\begin{array}{l}\text { After halothane and } \\
\text { suxamethonium, } \mathrm{MMS} \\
\text { with abdominal } \\
\text { rigidity. } \mathrm{ETCO}_{2} \text { off scale, } \\
\text { temp. } 40.8^{\circ} \mathrm{C} \text {, } \\
\mathrm{CK}(5 \text { days } \\
\text { postoperatively) } \\
11856\end{array}$ & Core myopathy & No cramps & 913 & 0.5 & 3.1 & 0.5 & 2.9 & MHS \\
\hline 38 & 14 & $\mathrm{~F}$ & $\begin{array}{l}\text { MMS following } \\
\text { thiopentone, atropine } \\
\text { and suxamethonium }\end{array}$ & $C C D$ & $\begin{array}{l}\text { Scoliosis since } \\
\text { childhood }\end{array}$ & 202 & 0.5 & 2.4 & 0.5 & 1.4 & MHS \\
\hline 39 & 11 & M & $\begin{array}{l}\text { ?CCD. After nitrous } \\
\text { oxide/halothane, } \\
\text { stiff all over. ?MH, } \\
\text { rectal temp. } 38.1^{\circ} \mathrm{C} \text {, } \\
\mathrm{CK} \text { next day } 9970\end{array}$ & $\begin{array}{l}\text { Relative's muscle: } \\
\text { cylindrical spirals }\end{array}$ & $\begin{array}{l}\text { Spinal and limb } \\
\text { problems. Cramps }\end{array}$ & 120 & $2.0^{*}$ & 0.3 & $32^{*}$ & 0 & $\mathrm{MHE}^{*}$ \\
\hline 63 & 41 & $\mathrm{~F}$ & $\begin{array}{l}\text { Muscle rigidity, } \\
\text { high CK, } \\
\text { hyperthermia with } \\
\text { halothane }\end{array}$ & Core myopathy & $\begin{array}{l}\text { Cramps in legs and } \\
\text { shoulders }\end{array}$ & 1828 & 0.5 & 3.25 & 1.5 & 0.45 & MHS \\
\hline 64 & 33 & M & $C C D$ referral & CCD & Cramps in all limbs & 492 & $>2$ & 0 & 4 & 0 & MHN \\
\hline 65 & 35 & $\mathrm{~F}$ & $\begin{array}{l}\text { MMS after } \\
\text { suxamethonium } \\
<24 \text { hrs stiffness }\end{array}$ & Core myopathy & No cramps & 422 & 0.5 & 6.1 & 1.5 & 1.5 & MHS \\
\hline 66 & 55 & M & $\begin{array}{l}\text { After sevoflurane, } \\
\text { increased ETCO, } \\
\text { HR } 145 \text {, temp. } 38.4^{\circ} \mathrm{C}\end{array}$ & Core myopathy & No cramps & 953 & 1 & 1 & 2 & 0.2 & MHS \\
\hline 67 & 27 & $\mathrm{~F}$ & $\begin{array}{l}\text { After isoflurane, } \\
\text { increased } \mathrm{ETCO}_{2} \text { and } \\
\text { HR, temp. } 37.3^{\circ} \mathrm{C} \text {, } \\
\text { CK } 56\end{array}$ & Core myopathy & No cramps & 41 & 2 & 0.5 & 1.5 & 0.5 & MHS \\
\hline 68 & 50 & $\mathrm{~F}$ & $C C D$ referral & $C C D$ & $\begin{array}{l}\text { No cramps. } \\
\text { Weakness in legs }\end{array}$ & 244 & $>2$ & 0 & 3 & 0 & MHN \\
\hline 69 & 15 & $\mathrm{~F}$ & $\begin{array}{l}\text { Muscle disease since } \\
\text { childhood, ?limb girdle } \\
\text { dystrophy. After } \\
\text { sevoflurane, ETCO } 26.6 \text {, } \\
\text { HR } 165 \text {, temp. } 38.5^{\circ} \mathrm{C} \text {, } \\
\text { CK920 }\end{array}$ & Features of CCD & $\begin{array}{l}\text { No cramps. } \\
\text { Weakness arms } \\
\text { and legs; some } \\
\text { wasting. Scoliosis }\end{array}$ & 1301 & 0.5 & 4.55 & 1 & 1.45 & MHS \\
\hline 70 & 10 & $\mathrm{~F}$ & $\begin{array}{l}\text { Known case of CCD/ } \\
\text { MmD. Poor muscle bulk. }\end{array}$ & $C C D$ & $\begin{array}{l}\text { No cramps. } \\
\text { Weak limbs }\end{array}$ & 44 & $>2$ & 0 & 4 & 0 & $\mathrm{MHN}$ \\
\hline 71 & 38 & M & $\begin{array}{l}\text { After halothane, } \\
\text { temp. } 39^{\circ} \mathrm{C} \text {, CK } 779\end{array}$ & Core myopathy & No cramps & 83 & $>2$ & 0 & 4 & 0 & MHN \\
\hline 72 & 29 & M & $\begin{array}{l}\text { After isoflurane, } \\
\mathrm{HR} 120, \mathrm{ETCO}_{2} 10.2, \\
\text { temp. } 39.5^{\circ} \mathrm{C} \text {, muscle } \\
\text { rigidity, } \mathrm{CK} 48000 \text {, } \\
\text { myoglobinuria., } \\
\text { muscle pain }\end{array}$ & Core myopathy & $\begin{array}{l}\text { Weakness in } \\
\text { legs }\end{array}$ & - & 1 & 2.1 & 1 & 1.45 & MHS \\
\hline $73(1 P)$ & 62 & $\mathrm{~F}$ & $\begin{array}{l}\text { Family history of } \\
C^{\prime} C D^{32}\end{array}$ & $\begin{array}{l}\text { Ice crystal } \\
\text { artefacts }\end{array}$ & No cramps & 29 & 2 & 0.75 & 1 & 1.3 & MHS \\
\hline $73(2 \mathrm{P})$ & 19 & M & $\begin{array}{l}\text { Grandmother CCD. } \\
\text { MMS after fractured } \\
\text { arm age } 11\end{array}$ & $\begin{array}{l}\text { Myopathic } \\
\text { changes }\end{array}$ & No cramps & 1324 & 1 & 2.7 & 1.5 & 1.05 & MHS \\
\hline
\end{tabular}




\begin{tabular}{|c|c|c|c|c|c|c|c|c|c|c|c|}
\hline \multirow[b]{2}{*}{$\begin{array}{l}\text { Family } \\
\text { (LMH) }\end{array}$} & \multirow[b]{2}{*}{$\begin{array}{l}\text { Age in } \\
\text { years at } \\
\text { biopsy }\end{array}$} & \multirow[b]{2}{*}{ Gender } & \multirow[b]{2}{*}{ History } & \multirow[b]{2}{*}{ Histology } & \multirow[b]{2}{*}{$\begin{array}{l}\text { Clinical features } \\
\text { of neuromuscular } \\
\text { disorders }\end{array}$} & \multirow{2}{*}{$\begin{array}{l}\text { CK IU/I } \\
\text { At time } \\
\text { of MH } \\
\text { biopsy }\end{array}$} & \multicolumn{4}{|c|}{ IVCT data§ } & \multirow[b]{2}{*}{$\begin{array}{l}\text { MH } \\
\text { status }\end{array}$} \\
\hline & & & & & & & $\begin{array}{l}\text { H } \\
\text { thr } \\
\%\end{array}$ & $\begin{array}{l}\text { H } \\
\text { contr } \\
\text { g }\end{array}$ & $\begin{array}{l}\text { C } \\
\text { thr } \\
\mathrm{mM}\end{array}$ & $\begin{array}{l}\text { C } \\
\text { contr } \\
\text { g }\end{array}$ & \\
\hline 74 & 10 & $\mathrm{~F}$ & Known case of $C C D$ & $C C D$ & $\begin{array}{l}\text { Proximal muscle } \\
\text { weakness }\end{array}$ & 52 & $>2$ & 0 & 3 & 0.1 & MHN \\
\hline 75 & 41 & $\mathrm{~F}$ & $\begin{array}{l}\text { After desflurane, } \\
\text { ETCO }_{2} 10.5 \text {, increased } \\
\text { a HR, temp. } 39.8^{\circ} \mathrm{C} \text {, } \\
\text { CK } 1621\end{array}$ & Type $2 b$ atrophy & No cramps & 74 & 1 & 0.7 & 3 & 0 & MHE \\
\hline
\end{tabular}

*Proband disabled and unable to be tested. Patient screened was next nearest relative.

**IVCT conducted before introduction of standardised EMHG diagnostic protocol..

§ IVCT data. Pre-test twitch of muscle specimens, indicative of specimen viability, were all above $1.0 \mathrm{~g}$ for each patient unless highlighted in bold.

$\mathrm{H}$ thr; , halothane IVCT threshold $=\%$ halothane where $0.2 \mathrm{~g}$ contracture recorded; C thr, caffeine IVCT threshold = mM concentration of caffeine where $0.2 \mathrm{~g}$ contracture recorded; $\mathrm{H}$ contr, halothane IVCT contracture = contracture in g following application of $2 \%$ halothane; C contr, caffeine IVCT contracture = contracture in g following application of $2 \mathrm{mM}$ caffeine.

$\mathrm{LMH}$, Leeds malignant hyperthermia unit, ${ }^{*} \mathrm{CCD}$, central core disease; $\mathrm{MH}$, malignant hyperthermia; $\mathrm{MmD}$, multi-mini core disease; $\mathrm{P}$, proband/index case; $\mathrm{HR}$, heart rate; ETCO, end tidal carbon dioxide test; MMS, muscle masseter spasm; MHS, susceptible to MH following IVCT; MHN, MH normal following IVCT; MHE, $\mathrm{MH}$ equivocal following IVCT, clinically considered at risk, indicates positive reaction to one of trigger agents only; $\mathrm{B}$, bolus, rather than incremental administration of $2 \%$ halothane.

CCD appears to be genetically heterogeneous. However, defects in the RYRl gene, which encodes a skeletal muscle calcium release channel, are predominant in the majority of cases. $^{7}{ }^{2122}$ Nevertheless, skeletal muscle cores characteristic of CCD have been reported in association with several other myopathies, and may implicate other loci as potential disease susceptibility candidates, such as:

- mutations in SEPNl on chromosome 1 , reported in association with $\mathrm{MmD}^{23}$

- defects in MYH7 on chromosome 14, reported in patients with hypertrophic cardiomyopathy ${ }^{24}$

- mutations in ACTAl on chromosome 1 and TNNTl on chromosome 19, in cases of nemaline myopathy. ${ }^{25} 26$

Thus, the apparent genetic heterogeneity may mirror the observed clinical heterogeneity and overlap reported in these disorders.

The RYRl gene locates to chromosome 19q13.1, encompassing $158 \mathrm{~Kb}$ of genomic DNA, and has 106 exons, two of which may be alternatively spliced. The cDNA sequence is $\sim 15 \mathrm{~Kb}$. At least 44 mutations have been reported in the gene in association with CCD, the majority of these being missense changes ${ }^{6722}{ }^{27-30}$ (unpublished data from the European Malignant Hyperthermia Group). Of the mutations identified, 33 locate to the C-terminal region (exons 90-106) which forms the calcium channel pore of the protein. As a result, the RYRl C-terminus has been identified as a CCD mutation hotspot.

We analysed RYRl in 21 families in whom CCD and MH status had been histologically and clinically characterised, and identified 12 mutations in 12 families (one mutation was recurrent and was detected in two families, and two mutations were detected in one family). On screening a panel of unrelated individuals susceptible to $\mathrm{MH}$, absence of $9 / 12$ of the identified mutations implied that these were likely to be specific to the CCD and/or the asymptomatic core myopathy observed in the families. Seven of the 12 mutations characterised were novel, four of which were detected in the C-terminus of RYRl. Our data support the hypothesis that the RYRl gene is a major genetic locus for CCD. Results also suggest that regions other than the Cterminus of RYRl have important roles in CCD pathogenesis, and that certain RYRl mutations may be specific to CCD patients with or without MH. Finally, the role of other candidate susceptibility loci should not be excluded from study of the aetiology of CCD.

\section{METHODS}

Clinical features and IVCT results for probands are given in table 1. For the purposes of discussion relevant to this report, we refer to patients as having CCD when histological and clinical signs of the disease have been recorded. Those cases with only histological signs are referred to as patients with core myopathy. All patients were referred to the Leeds $\mathrm{MH}$ Unit because of the risk of $\mathrm{MH}$ susceptibility (previous known/suspected $\mathrm{MH}$ reaction or case of CCD), and $\mathrm{MH}$ status was therefore assessed by the contracture test in the laboratory using a specimen of patient skeletal muscle. An MHS phenotype is diagnosed by a contracture of $0.2 \mathrm{~g}$ or above at a threshold dose of halothane $(2 \%)$, and separately to caffeine $(2 \mathrm{mM}) .^{13}$

Genomic DNA was extracted from whole blood samples using a salting out method. ${ }^{31}$ Haplotypes were constructed for families of suitable size (LMH31,32, 33, 34, 36, 37, 38, 39, 65, 75 , table 1) using markers to the RYRl region (D19S208 [0.9cM]- D19S224 -[2.3cM]- D19S421-[0.3cM]- D19S422 [6.8cM]- D19S219 -[0.4cM]- CTG-DM -[0.1cM]- D19S112). Where samples were available, the family proband and a clinically normal relative were selected for mutation detection, which was performed using specific or mutation scanning assays. Detection of 21 known mutations was carried out using PCR and restriction digest assays. These involved: Thr2206 Met, ${ }^{33}$ Arg2454Cys, ${ }^{34}$ Arg2454His, ${ }^{35}$ Thr4637Ala, ${ }^{36}$ Tyr4796Cys, ${ }^{6}$ Ile4898Thr, ${ }^{37}$ and 15 mutations: Cys35Arg, Arg163Cys, Gly248Arg, Gly341Arg, Ile403Met, Tyr522Ser, Arg552Trp, Arg614Cys, Arg614Leu, Arg2163Cys, Arg2163His, Gly2434Arg, Arg2435His, Arg2458Cys, and Arg2458His. ${ }^{15}$ Further screening was undertaken by fluorescent SSCP (F-SSCP) analysis (exons 6, 11, 17, 39-46) and cycle sequencing using an ABI 377 (exons 91, 95-106). Primers for F-SSCP and cycle sequencing were designed to the flanking intronic sequence to ensure full exon coverage. For F-SSCP, test samples were analysed in comparison with wild type and mutation positive control samples where available, on IX MDE gels (Flowgen; Ashby de la Zouch, UK) run at $18^{\circ} \mathrm{C}$ using $1 X$ TBE buffer. Any shifts detected were sequenced to characterise the nature of the change.

For novel mutations identified, a mutation specific assay was designed (table 2) in order to perform segregation analysis within mutation positive families. A panel of 200 unrelated MHS and 100 normal control samples were also screened, to assess the prevalence of the mutation in the UK MH population, and to establish whether the variant detected was likely to be a neutral 
Table 2 Primer sequences and conditions for detection of novel mutations

\begin{tabular}{|c|c|c|c|c|c|}
\hline Mutation* & & Primer sequence $\left(5^{\prime}-3^{\prime}\right)$ & & $\begin{array}{l}\text { Annealing } \\
\text { temp. }{ }^{\circ} \mathrm{C}\end{array}$ & $\begin{array}{l}\text { Product size } \\
\text { bp }\end{array}$ \\
\hline $479 A>G$ & ARMS & AAGCAGAGGTCTGAAGGCGG* & CAGACCTGGGAGCAGGAG & 58 & 113 \\
\hline $7036 G>A$ & $\begin{array}{l}\text { RFLP (gain of Nlalll site with } \\
\text { mutation) }\end{array}$ & GGACCTGTGTTACCCTGGAGT & TTGCСTATTGAGGAGGGGGC & 60 & 121 \\
\hline $7043 A>G$ & ARMS & CCAGGCGAGAGCGTGGCTGA* & CGGGTTGCCTATTGAGGAG & 55 & 227 \\
\hline $14440 \mathrm{C}>\mathrm{T}$ & ARMS & CTTCTTCTTTGCTGCCCGTT* & ТАТСССТTСАССАСССАСТ & 55 & 162 \\
\hline $14471 T>C$ & ARMS & CATGGGGGTCAAGACACC* & TCAGTCCCTGTGGCTCTACC & 56 & 222 \\
\hline $14814 C>G$ & $\begin{array}{l}\text { RFLP (loss of Taql site with } \\
\text { mutation) }\end{array}$ & GTCGGGCACTGACTTGTGT & AAGTACCCCACTGCTGGCTA & 58 & 355 \\
\hline $14817 C>A$ & ARMS & CCCCAGGTCTGATCATCTAA* & CGGCCTGGAGGTACCATTAT & 55 & 162 \\
\hline
\end{tabular}

polymorphism or pathogenic mutation. The site of the mutation in the RYRl protein was also examined to determine whether it had been conserved among species and was therefore likely to be of functional significance (table 3 ).

\section{RESULTS}

\section{Linkage analysis}

Family size restricted linkage analysis to 10/21 families. Nine of these families showed haplotypes compatible with linkage of CCD/MH to RYRl. An RYRl mutation, which cosegregated with the chromosome 19 haplotype, was identified in six of the nine families (LMH31, LMH33, LMH34, LMH36, LMH65, LMH75, table 3). In the three families where a mutation was not identified, a common chromosome 19 haplotype cosegregated with the MH positive / CCD positive phenotype in two families (LMH37 and LMH38), in contrast to LMH39 where the haplotype segregated with core myopathy observed rather than MH. In family LMH32, a single recombinant core

Table 3 Summary of mutation results

\begin{tabular}{|c|c|c|c|c|c|c|c|c|}
\hline \multirow[b]{2}{*}{$\begin{array}{l}\text { Family } \\
\text { (LMH) }\end{array}$} & \multirow[b]{2}{*}{ Status } & \multicolumn{5}{|c|}{ Mutation status } & \multicolumn{2}{|c|}{ Segregation of mutation } \\
\hline & & Exon & $\begin{array}{l}\text { Nucleotide } \\
\text { change }\end{array}$ & $\begin{array}{l}\text { Amino acid } \\
\text { change }\end{array}$ & $\begin{array}{l}\text { +Conserved } \\
\text { RYRI site? }\end{array}$ & $\begin{array}{l}\text { Method of } \\
\text { detection }\end{array}$ & $\begin{array}{l}\text { Concorda } \\
\text { family CC }\end{array}$ & $\begin{array}{l}\text { Concordant } \\
\text { family MH }\end{array}$ \\
\hline 31 & $\mathrm{MH} / \mathrm{CCD}$ & 95 & $13913 \mathrm{G}>\mathrm{A} \ddagger$ & Gly4638Asp & Yes* $^{*}$ & Sequencing & Yes & No \\
\hline 32 & $\begin{array}{l}\mathrm{MH} / \text { core } \\
\text { myopathy }\end{array}$ & - & & & & & & \\
\hline 33 & $\mathrm{MH} / \mathrm{CCD}$ & 6 & $479 A>G$ & Glu160Gly & Yes & $\begin{array}{l}\mathrm{SSCP}, \\
\text { sequencing }\end{array}$ & Yes & Yes \\
\hline $34(1 P)$ & $\mathrm{MH} / \mathrm{CCD}$ & 95 & $13913 \mathrm{G}>\mathrm{A} \ddagger$ & Gly4638Asp & Yes* $^{*}$ & Sequencing & Yes & No \\
\hline $34(2 P)$ & $M H / C C D$ & 95 & $13913 G>A \ddagger$ & Gly4638Asp & Yes* & Sequencing & Yes & No \\
\hline 36 & $\mathrm{MH} / \mathrm{CCD}$ & 103 & $14814 C>G$ & lle4938Met & Yes & Sequencing & No & Yes \\
\hline 37 & $\begin{array}{l}\mathrm{MH} / \text { core } \\
\text { myopathy }\end{array}$ & - & & & & & & \\
\hline 38 & $\mathrm{MH} / \mathrm{CCD}$ & - & & & & & & \\
\hline 39 & $\mathrm{MH} / \mathrm{CCD}$ & - & & & & & & \\
\hline 63 & $\begin{array}{l}\mathrm{MH} / \text { core } \\
\text { myopathy }\end{array}$ & $\begin{array}{l}44 \\
103\end{array}$ & $\begin{array}{l}7036 G>A, \\
14817 C>A\end{array}$ & $\begin{array}{l}\text { Val2346Met, } \\
\text { Asp4939Glu }\end{array}$ & Yes & $\begin{array}{l}\mathrm{SSCP} \text {, } \\
\text { sequencing }\end{array}$ & Yes, Yes & Yes, Yes \\
\hline 64 & $C C D$ & - & & & & & & \\
\hline 65 & $\begin{array}{l}\mathrm{MH} / \text { core } \\
\text { myopathy }\end{array}$ & 44 & $7043 A>G$ & Glu2348Gly & Yes & $\begin{array}{l}\mathrm{SSCP} \text {, } \\
\text { sequencing }\end{array}$ & No & Yes \\
\hline 66 & $\begin{array}{l}\mathrm{MH} / \text { core } \\
\text { myopathy }\end{array}$ & 17 & $1840 \mathrm{C}>\mathrm{T} \dagger$ & Arg614Cys & Yes & RFLP & No & Yes \\
\hline 67 & $\begin{array}{l}\mathrm{MH} / \text { core } \\
\text { myopathy }\end{array}$ & - & & & & & & \\
\hline 68 & $C C D$ & 100 & $14440 C>T$ & Leu4814Phe & Yes & Sequencing & Yes & No \\
\hline 69 & $\mathrm{MH} / \mathrm{CCD}$ & - & & & & & & \\
\hline 70 & $C C D$ & - & & & & & & \\
\hline 71 & $\begin{array}{l}\text { Core } \\
\text { myopathy }\end{array}$ & - & & & & & & \\
\hline 72 & $\begin{array}{l}\mathrm{MH} / \text { core } \\
\text { myopathy }\end{array}$ & 100 & $14471 T>C$ & Leu4824Pro & Yes & Sequencing & Yes & Yes \\
\hline 73 (1P) & $\mathrm{MH} / \mathrm{CCD}$ & 46 & $7354 \mathrm{C}>\mathrm{T} \S$ & Arg2452Trp & Yes & $\begin{array}{l}\mathrm{SSCP}, \\
\text { sequencing }\end{array}$ & No & Yes \\
\hline $73(2 P)$ & $\mathrm{MH} / \mathrm{CCD}$ & 46 & $7354 \mathrm{C}>\mathrm{T} \S$ & Arg2452Trp & Yes & $\begin{array}{l}\mathrm{SSCP} \text {, } \\
\text { sequencing }\end{array}$ & No & Yes \\
\hline 74 & $C C D$ & 101 & $14582 \mathrm{G}>\mathrm{A}$ & Arg4861His & Yes & Sequencing & Yes & No \\
\hline 75 & $\begin{array}{l}\text { MH/core } \\
\text { myopathy }\end{array}$ & 46 & $7373 G>A^{* *}$ & Arg2458His & Yes & SSCP & No & Yes \\
\hline \multicolumn{9}{|c|}{ 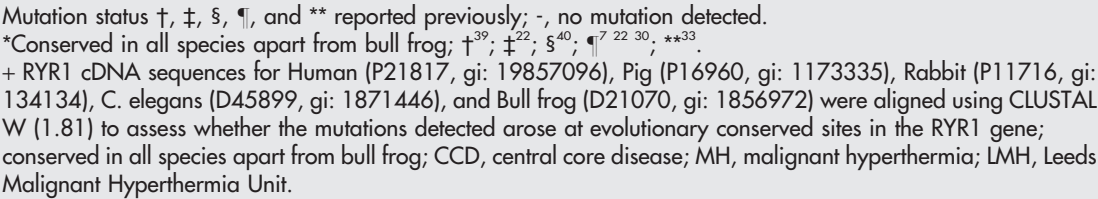 } \\
\hline
\end{tabular}


myopathy / MHS individual was observed for the high risk susceptibility haplotype. Further investigations are in progress to characterise the putative disease susceptibility locus in this family.

\section{RYR 1 mutation analysis}

Of 20 RYRl mutations screened, a known, functional $\mathrm{MH}$ mutation-LMH66 with $1840 \mathrm{C}>\mathrm{T}$ - was found in one family. Histological analysis for this patient showed core myopathy, and the patient was also IVCT MHS (tables 1 and 3).

F-SSCP of 11 candidate exons, representing mutation hotspot regions 1 and 2 of RYRl, detected 10 shifts. All shifts were sequenced; five missense mutations, three novel (table 3), and five neutral polymorphisms were identified (data not shown). Of the three novel mutations: $479 \mathrm{~A}>\mathrm{G}$ was detected in family LMH33 (CCD/MHS); 7043A $>\mathrm{G}$ in family LMH65 (core myopathy / MHS); and 7036G $>$ A in family LMH63 (core myopathy / MHS). Of the two previously reported mutations: $7373 \mathrm{G}>\mathrm{A}$ was detected in LMH75 (family with evidence of non-specific type-2b atrophy / CCD/MHS); and $7354 \mathrm{C}>\mathrm{T}$ was detected in LMH73 (family history of $\mathrm{CCD} / \mathrm{MHS}$ ).

Sequencing of $13 \mathrm{C}$-terminal exons, representing mutation hotspot region 3 of RYRl, identified six missense mutations: four novel and two previously reported (table 3); and also four neutral polymorphisms (data not shown). The four novel mutations were: 14440C $>$ T in family LMH68 (CCD/ MHN); 14471T >C in family LMH72 (core myopathy / MHS); $14814 \mathrm{C}>\mathrm{G}$ in family LMH36 (CCD/MHS); and $14817 \mathrm{C}>\mathrm{A}$ in family LMH63 (core myopathy / MHS). Of the two previously reported mutations: $13913 \mathrm{G}>\mathrm{A}$ was detected in families LMH31 (CCD/MHS) and LMH34 (CCD/MHS); and $14582 \mathrm{G}>\mathrm{A}$ was detected in family LMH74 (CCD/MHN).

\section{Prevalence of mutations in the UK population}

Mutation specific assays were designed for all novel mutations detected (table 2). The prevalence within the UK MHS population (sample of 200 subjects) and a UK normal control population (sample of 100 subjects) was assessed. Of the mutations identified within the sample, 1840C $>$ T, 7373G $>$ A, and $14471 \mathrm{~T}>\mathrm{C}$ were detected in the unrelated screened MHS population. There was no evidence in this population of CCD in $1840 \mathrm{C}>\mathrm{T}: 6$ families, $7373 \mathrm{G}>\mathrm{A}: 6$ families, or $1447 \mathrm{lT}>\mathrm{C}: 3$ families. Mutation 13913G $>$ A was recurrent in two CCD/ MHS families-LMH31 and LMH34. Remaining mutations detected occurred in isolated cases only, and were not detected in the unrelated MHS population screened, nor in the 100 normal controls. All novel mutations identified occurred at evolutionary conserved sites, indicating a site of functional significance within the protein (table 3 ).

Segregation analysis was conducted in all mutation positive families where DNA samples were available (table 3). In 3/12 mutation positive families, each mutation detected was concordant with both the CCD and MHS phenotypes: mutations 479A $>\mathrm{G}, 7036 \mathrm{G}>\mathrm{A}, 1447 \mathrm{lT}>\mathrm{C}$, and $14817 \mathrm{C}>\mathrm{A}$, where $7036 \mathrm{G}>\mathrm{A}$ and $14817 \mathrm{C}>\mathrm{A}$ were detected in one family. In 5/12 families, the mutation was concordant with $\mathrm{MH}$ status only $(1840 \mathrm{C}>\mathrm{T}, 7043 \mathrm{~A}>\mathrm{G}, 7373 \mathrm{G}>\mathrm{A}$, $7354 \mathrm{C}>\mathrm{T}, 14814 \mathrm{C}>\mathrm{G})$. In $4 / 12$ families, the mutation detected was concordant with CCD status only $(13913 \mathrm{G}>\mathrm{A}$ detected in two families, $14440 \mathrm{C}>\mathrm{T}, \mathrm{14582 \textrm {G }}>\mathrm{A}$ ). These data imply that mutations in RYRl may be specific to CCD and/or MHS, and that further variants may be responsible for the CCD pathology and MH susceptibility within some families.

\section{DISCUSSION}

We screened 21 individuals of UK origin with core myopathy or CCD, diagnosed on the basis of histological findings with or without clinical presentation and assessed for MHS by the
IVCT. We identified RYRl mutations in 12 families. Only one mutation was recurrent in two families. In one family two mutations were detected. This analysis gives an overall mutation detection rate of $57 \%$. The mutations identified can be classified into four distinct groups:

- those that cosegregate with the CCD and MHS phenotype (change at nucleotide 479)

- those that cosegregate with histologically diagnosed core myopathy and MHS phenotype (changes at nucleotides 7036, 14471, 14817)

- those that cosegregate with CCD only (changes at nucleotides 13913, 14440, 14582)

- those that appear specific to the MHS phenotype (changes at nucleotides $1840,7043,7354,7373,14814)$.

Therefore, in line with previous reports, mutations in RYRl specifically associated with CCD appear to cluster in Cterminal exons of the gene (exons 95, 100, 101, in our patient sample). However, it is evident that mutations in N-terminal regions-exon 6-may also be associated with a CCD/MHS phenotype. Conversely, mutations in the C-terminus may give rise to MHS in the absence of CCD-for example, exon 103 and $14814 \mathrm{C}>\mathrm{G}$ in LMH36.

CCD is the only myopathy that has been consistently reported in association with $\mathrm{MH}$. It exhibits extensive histological and clinical variability within and between families. Histological examination shows cores in type 1 muscle fibres and type 1 fibre predominance. ${ }^{19}$ There are also reports of worsening clinical status from one generation to another. ${ }^{7}$ Patients with $\mathrm{MH}$ may also present with cores, despite clinically being asymptomatic of CCD. The boundaries of CCD diagnosis with respect to the extent of myopathic changes on histological examination are unclear. At least three CCD families within the cohort studied also had members who were either:

- clinically affected with CCD and MH positive

- or positive for $\mathrm{MH}$, with core myopathy on histology but without clinical CCD

- or MH positive with no clear myopathic changes

- or MH negative and CCD positive.

The variation in phenotype observed within the same family could reflect incomplete penetrance for CCD which has been described in association with some RYRl mutations, ${ }^{38}$ the mildly progressive nature of CCD reported in some individuals, ${ }^{32}$ or the independent segregation of $\mathrm{MH}$ and CCD within some families. Because of the observed phenotypic overlap, we investigated patients presenting with CCD and asymptomatic patients showing core myopathy following histological examination.

Patients with CCD are at high risk of MHS, and in almost all cases are diagnosed MHS positive by the IVCT-for example $7 / 11(64 \%)$ in our study. Within the entire cohort of 23 probands (from 21 families), 18 gave a positive response on IVCT $(78 \%)$. Five cases were clearly IVCT $\mathrm{MH}$ normal (table 1). Of the $18 \mathrm{MH}$ positive IVCT cases, investigation of further family members showed CCD positive and $\mathrm{MH}$ normal individuals to be present in two families (LMH31, LMH34). In seven families, CCD/core myopathy negative MHS individuals were also identified (LMH32, LMH36, LMH65, LMH66, LMH67 LMH73, LMH75). This substantiates the concept that CCD / core myopathy and $\mathrm{MH}$ may exist independently within families. In characterisation of pathogenic mutations, some variants clearly predispose to both $\mathrm{MH}$ and CCD, others being disease specific. Candidates include specific mutations within RYRl, or at sites in alternative loci. We identified one family (LMH63) presenting with MHS and 
core myopathy with two mutations in RYRl. One mutation may be specific for the core myopathy observed because of its location to the $\mathrm{C}$-terminus $(14817 \mathrm{C}>\mathrm{A})$, the other for predisposition to MHS (7036G $>$ A). Neither mutation was detected on screening a panel of normal control samples, and both occur at evolutionary conserved sites within the RYRl protein, evidence which supports the concept that both mutations may have some functional consequence. A second family, LMH32, did not display haplotypes compatible with linkage to the RYRl region, confirming the possible role of alternative susceptibility loci in CCD / core myopathy aetiology. Work is ongoing for the analysis of this family.

Of the 12 mutations identified, five are known. In contrast to other studies, none of the cases represented sporadic events, ${ }^{72}$ but were reported as follows:

- mutation $7354 \mathrm{C}>\mathrm{T}$ in association with $\mathrm{MH}$ in a New Zealand family ${ }^{39}$

- mutation 13913G >A in a sporadic case of CCD in an Australian family ${ }^{22}$

- mutation $14582 \mathrm{G}>\mathrm{A}$ in

- two Australian CCD families (one sporadic case and one with a family history of $\mathrm{CCD}^{22}$ )

- three French CCD families (one sporadic case, two with a family history of $\mathrm{CCD}^{7}$ )

- seven families of mixed European origin, all of which had a family history of CCD. ${ }^{30}$

The remaining two mutations, $1840 \mathrm{C}>\mathrm{T}$ and $7373 \mathrm{G}>\mathrm{A}$, did not show concordance with the core myopathy phenotype observed in the families, although $1840 \mathrm{C}>\mathrm{T}$ and mutation $7372 \mathrm{C}>\mathrm{T}$, which alters the same amino acid residue as $7373 \mathrm{G}>\mathrm{A}$, have both been previously described in association with $\mathrm{MH}$ and asymptomatic cores. ${ }^{36}$ Our findings imply either that additional genetic determinants may predispose to CCD/ asymptomatic cores in these cases, or that penetrance is incomplete. Overall, the spectrum of mutations reported for CCD is diverse, the majority being private to individual families. To date, the $14582 \mathrm{G}>\mathrm{A}$ mutation is the most commonly reported CCD mutation.

The functional consequences of missense mutations are difficult to predict. Certain RYRl mutations have been more fully characterised using a model system in the laboratory by analysis of either recombinant RYRl channels expressed in a heterologous system, ${ }^{63741-43}$ or myotubes / lymphoblastoid cells isolated and cultured from mutation carriers..$^{3044}$ Differences in calcium flux between mutant and wild type RYRl channels / cell preparations have been demonstrated. Few mutations can be distinguished on the basis of their relative sensitivity to specific calcium release trigger agents. ${ }^{41}{ }^{42}$ However, there is some evidence from analysis of recombinant RYRl channels in the laboratory, ${ }^{37}$ and from RYRl genotype/IVCT phenotype correlation studies, ${ }^{33}{ }^{46}$ that certain CCD/MH RYRl mutations are associated with more severe phenotypes compared with RYRl mutations reported principally in association with $\mathrm{MH}$.

In skeletal muscle excitation contraction (EC) coupling, the dihydropyridine receptor (DHPR) and the ryanodine receptor (RyR) are linked mechanically. The DHPR undergoes a voltage / calcium induced conformational change, which in turn triggers RyR calcium release and ultimately muscle contraction. One proposed functional consequence of RYRl mutations associated with CCD is to increase the permeability of the RYRl channel to calcium; another mechanism may be functional uncoupling of SR calcium release from sarcolemmal depolarisation. Muscle weakness is thought to arise because of the reduction in available sarcolemmal calcium for the normal process of muscle contraction.
Alternatively, persistent calcium leak from the sarcolemma could predispose muscle damage and therefore weakness. ${ }^{46}$ Seven CCD mutations (G4890R, I4897T, I4898T, G4898E, G4898R, A4905V, and R4913G) have so far been found to give rise to an EC uncoupled SR calcium release channel. ${ }^{36} 47$ Locating to exon 102 of the gene, and the region contributing to the RYRl channel pore (residues 4861 to $4918^{48}$ ), other mutations in this area may have the same effect. One mutation identified in this study, Arg4861His; 14582G>A, locates to this interval, with mutations Arg4939Glu, 14817C $>$ A, and Ile4938Met (14814C $>$ G being close to the boundary of the pore encoding region). Data from analysis of 14582G $>$ A mutant lymphoblastoid cell lines support a pathological mechanism of channel leakiness. ${ }^{30}$ Only two other mutations identified in the study, $1840 \mathrm{C}>\mathrm{T}$ and $7373 \mathrm{G}>\mathrm{A}$, have been characterised in an independent system in the laboratory and shown to alter the normal functioning of the RYRl channel. ${ }^{41}{ }^{42}$

In summary, we have identified RYRl mutations in $57 \%$ of the families investigated. Three mutations were specific to the CCD phenotype (13913G>A, 14440C $>$ T, 14582G $>A$ ). Four mutations cosegregated with the CCD and MHS phenotype in three families (mutation $479 \mathrm{~A}>\mathrm{G}$ in a family with $\mathrm{CCD} / \mathrm{MH}$, and mutations 14471C $>\mathrm{T}, \quad 7036 \mathrm{G}>\mathrm{A} /$ $14817 \mathrm{C}>\mathrm{A}$ in two MHS families presenting with core myopathy). In five families, the mutation detected cosegregated with the MHS phenotype only, showing discordance with CCD and/or core myopathy in at least one individual $(1840 \mathrm{C}>\mathrm{T}, 7043 \mathrm{~A}>\mathrm{G}, 7354 \mathrm{C}>\mathrm{T}, 7373 \mathrm{G}>\mathrm{A}, 14814 \mathrm{C}>\mathrm{G})$. This indicates that specific RYRI mutations predispose to MHS or CCD, and that others may predispose to both CCD and/or core myopathy in addition to MH. Mutations which segregated specifically with CCD status were detected in the C-terminal region of the RYRl gene only. For the purposes of molecular characterisation of CCD patients, with a wide spectrum of RYRl mutations now reported in individual families, the Cterminal region of the gene remains the primary site for initial investigation and mutation screening. It is, however, important to recognise that mutations in other regions of the RYRl gene may also occur, and that the risk to MHS is significant and should be investigated initially by the IVCT in the family index case.

\section{ACKNOWLEDGEMENTS}

We would like to thank the British Malignant Hyperthermia Association for their financial support of this work.

\section{Authors' affiliations}

S Shepherd, F Ellis, J Halsall, P Hopkins, R Robinson, Academic Unit of Anaesthesia, Clinical Sciences Building, St James University Hospital, Leeds, UK

Correspondence to: R Robinson, Academic Unit of Anaesthesia, MH Unit, Clinical Sciences Building, St James University Hospital, Leeds, LS9 7TF, UK; medrlr@stjames.leeds.ac.uk

Received 8 September 2003

Accepted 7 October 2003

\section{REFERENCES}

1 Shy G, Magee K. A new congenital non-progressive myopathy. Brain 1956;79:610-21.

2 Jurkat-Rott K, Lerche H, Lehmann-Horn F. Skeletal muscle channelopathies. J Neurol 2002;249:1493-1502.

3 Shuaib A, Paasuke RT, Brownell AKW. Central core disease: clinical features in 13 patients. Medicine 1987:66:389-96.

4 Manzur AY, Sewry CA, Ziprin J, Dubowitz V, Muntoni F. A severe clinical and pathological variant of central core disease with possible autosomal recessive inheritance. Neuromuscul Disord 1998;8:467-73.

5 Ferreiro A, Monnier N, Romero N, Leroy J-P, Bonnemann C, Haenggeli C-A Straub V, Wolfgang D, Voss M, Nivoche $Y$, Jungbluth $H$, Lemainque A, Voit $T$, Lunardi J, Fardeau M, Guicheney. A recessive form of central core disease 
transiently presenting as multi-minicore disease, is associated with a homozygous mutation in the ryanodine receptor type 1 gene. Ann Neurol 2002;51:750-9.

6 Monnier N, Beatriz Romero N, Lerale J, Nivoche Y, Qi D, MacLennan D Fardeau $M$, Lunardi J. An autosomal dominant congenital myopathy with cores and rods is associated with a neomutation in the RYR1 gene encoding the skeletal muscle ryanodine receptor. Hum Mol Genet 2000;9:2599-608.

7 Monnier N, Beatriz Romero N, Lerale J, Landrieu P, Nivoche Y, Fardeau M Lunardi J. Familial and sporadic forms of central core disease are associated with mutations in the $\mathrm{C}$-terminal domain of the skeletal muscle ryanodine receptor. Hum Mol Genet 2001;10:2581-92.

8 Brownell AKW. Malignant hyperthermia: relationship to other diseases. Br J Anaesth 1998;60:303-8.

9 McCarthy T, Quane K, Lynch P. Ryanodine receptor mutations in malignant hyperthermia and central core disease. Hum Mutat 2000;15:410-17.

10 Robinson RL, Curran JL, Hall WJ, Halsall PJ, Hopkins PM, Markham AF, Stewart AD, West SP, Ellis FR. Genetic heterogeneity and HOMOG analysis in British malignant hyperthermia families. J Med Genet 1998;35:196-201.

11 Mickelson JR, Lovis CF. Malignant hyperthermia-excitation-contraction coupling $\mathrm{Ca}^{2+}$ release channel, and cell $\mathrm{Ca}^{2+}$ regulation defects. Physiological Reviews 1996;76:537-92.

12 Hopkins PM. Malignant hyperthermia: advances in clinical management and diagnosis. Br J Anaesth 2000;85:118-28.

13 European Malignant Hyperpyrexia Group. A protocol for the investigation of malignant hyperpyrexia susceptibility. Br J Anaesth 1984;56:1267-9.

14 European Malignant Hyperpyrexia Group. Laboratory diagnosis of malignant hyperpyrexia susceptibility. Br J Anaesth 1985;57:1038.

15 Urwyler A, Deufel T, McCarthy T, West S. Guidelines for the molecular detection of susceptibility to malignant hyperthermia. $\mathrm{Br} J$ Anaesth $2001 ; 86: 283-7$

16 Islander G, Henriksson K-G, Ranklev-Twetman E. Malignant hyperthermia susceptibility without central core disease (CCD) in a family where CCD is diagnosed. Neuromuscul Disord 1993;5:125-7.

17 Curran JL, Hall WL, Halsall PJ, Hopkins PM, Iles DE, Markham AF, McCall SH, Robinson RL, West SP, Bridges LR, Ellis FR. Segregation of malignant hyperthermia, central core disease and chromosome 19 markers. Br J Anaesth 1999;83:217-22.

18 Lamont P, Dubowitz V, Landon D, Davis M, Morgan-Hughes J. Fiffy year follow-up of a patient with central core disease shows slow but definite progression. Neuromuscul Disord 1998;8:385-91.

19 Cauwer HD, Heytens L, Martin JJ. Workshop report of the $89^{\text {th }}$ ENMC International Workshop. Central core disease. Neuromuscul Disord 2002;12:588-95.

20 laizzo P, Lehmann-Horn. Anaesthetic complications in muscle disorders. Anaesthesiology 1995;82:1093-6.

21 Kausch K, Lehmann-Horn F, Janka M, Wieringa B, Grimm T, Mueller C. Evidence for linkage of the central core disease locus to the proximal long arm of Human chromosome 19. Genomics 1991;10:765-9.

22 Davis $M$, Haan E, Jungbluth $H$, Sewry $C$, North K, Muntoni F, Kuntzer T, Lamont $\mathrm{P}$, Bankier A, Tomlinson P, Sanchez A, Walsh P, Nagarajan L, Oley C, Colley A, Gedeon A, Quinlivan R, Dixon J, James D, Mueller C, Lang N. Principle mutation hotspot for central core disease and related myopathies in the C-terminal transmembrane region of the RYR1 gene. Neuromuscul Disord 2003; 13:151-7.

23 Ferreiro A, Quijano-Roy S, Pichereau C, Moghadaszadeh B, Goemans N, Bonnemann $C$, Jungbluth $H$, Straub V, Villanova M, Leroy J-P, Romero N, Martin J, Muntoni F, Voit T, Estournet B, Richard P, Fardeau M, Guicheney. Mutations of the selenoprotein $\mathrm{N}$ gene, which is implicated in rigid spine muscular dystrophy, cause the classical phenotype of multiminicore disease: reassessing the nosology of early-onset myopathies. Am J Hum Genet 2002;71:739-49.

24 Fananapazir L, Dalakas M, Cyran F, Cohn G, Epstein N. Missense mutations in the beta-myosin heavy-chain gene cause central core disease in hypertrophic cardiomyopathy. Proceedings of National Academy of Sciences 1993:90:3993-7.

25 Ilkovski B, Cooper S, Nowak K, Ryan M, Yang N, Schnell C, Durling H, Roddick L, Wilkinson I, Kornberg A, Collins K, Wallace G, Gunning P, Hardeman E, Laing N, North K. Nemaline myopathy caused by mutations in the muscle alpha-skeletal-actin gene. Am J Hum Gene 2001;68:1333-1343.

26 Johnston J, Kelley R, Crawford T, Holmes Morton D, Agarwala R, Koch T, Schaffer A, Francomano C, Biesecker L. A novel nemaline myopathy in the Amish caused by a mutation in Troponin T1. Am J Hum Genet 2000;67:814-21.

27 Quane KA, Healy JM, Keating KE, Manning BM, Couch FJ, Palmucci LM, Doriguzzi C, Fagerlund TH, Berg K, Ording H. Mutations in the ryanodine receptor gene in central core disease and malignant hyperthermia. Nat Genet 1993:5:51-5.

28 Quane KA, Keating KE, Healy JM, Manning BM, Krivosic-Horber R, Krivosic I, Monnier N, Lunardi J, McCarthy TV. Mutation screening of the RYRl gene in malignant hyperthermia: detection of a novel Tyr to Ser mutation in a pedigree with associated central cores. Genomics 1994;23:236-9.

29 Zhang Y, Chen HS, Khanna VK, De Leon S, Phillips MS, Schappert K, Britt BA, Brownell AK, MacLennan DH. A mutation in the human ryanodine receptor gene associated with central core disease. Nat Genet 1993;5:46-50.

30 Tilgen N, Zorzato F, Halliger-Keller B, Muntoni F, Sewry C, Palmucci L, Schneider C, Hauser E, Lehmann-Horn F, Mueller C, Treves S. Identification of four novel mutations in the $\mathrm{C}$-terminal membrane spanning domain of the ryanodine receptor: association with central core disease and alteration of calcium homeostasis. Hum Mol Genet 2001;10:2879-87.

31 Miller SA, Dykes DD, Polesky HF. A simple salting out procedure for extracting DNA from human nucleated cells. Nucleic Acids Res 1988;343:562-4.

32 Patterson VH, Hill TR, Fletcher PJ, Heron JR. Central core disease. Clinical and pathological evidence of progression within a family. Brain 1979;102:581-94

33 Manning B, Quane K, Ording H, Urwyler A, Tegazzin V, Lehane M O'Halloran J, Hartung E, Giblin L, Lynch P, Vaughan P, Censier K, Bendixen D, Comi G, Heytens L, Monsieurs K, Fagerlund T, Wolz W, Heffron J, Muller C, McCarthy T. Identification of novel mutations in the ryanodine receptor gene (RYR 1) in malignant hyperthermia; genotype-phenotype correlation. Am J Hum Genet 1998:62:599-609.

34 Brandt A, Schleithoff L, Jurkatt-Rott K, Klingler W, Baur C, Lehmann-Horn F. Screening of the ryanodine receptor gene in 105 malignant hyperthermia families; novel mutations and concordance with the in vitro contracture test. Hum Mol Genet 1999:8:2055-62.

35 Barone V, Massa O, Intravaia E, Bracco A, Di Martino A, Tegazzin V, Cozzolino S, Sorrentino V. Mutation screening of the RYR1 gene and identification of two novel mutations in Italian malignant hyperthermia families. J Med Genet 1999;36:115-18.

36 Lynch P, Tong J, Lehane M, Mallet A, Giblin L, Heffron J, Vaughan P, Zafra G, MacLennan D, McCarthy T. A mutation in the transmembrane domain of the ryanodine receptor is associated with abnormal $\mathrm{Ca}^{2+}$ release channel function and severe central core disease. Proceedings of National Academy of Sciences 1999:96:4164-9

37 Sewry C, Muller C, Davis M, Dwyer J, Dove J, Evans G, Scroder R, Furst D, Helliwell T, Laing N, Quinlivan R. The spectrum of pathology in central core disease. Neuromuscul Disord 2002;12:930-8

38 Gillard E, Otsu K, Fujii J, Khanna V, De Leon S, Derdemezi J, Britt B, Duff C, Worton R, MacLennan D. A substitution of cysteine for argentine 614 in the ryanodine receptor is potentially causative of human malignant hyperthermia. Genomics 1991;11:751-5.

39 Chamley D, Pollock N, Stowell K, Brown R. Malignant hyperthermia in infancy and identification of novel RYR1 mutation. Br J Anaesth 2000;84:500-4.

40 Tong J, Hideto O, Demaurex N, Grinstein S, McCarthy T, MacLennan D. Caffeine and halothane sensitivity of intracellular $\mathrm{Ca} 2+$ release is altered by 15 calcium release channel (ryanodine receptor) mutations associated with malignant hyperthermia and/or central core disease. J Biol Chem 1997; 272:26332-9.

41 Tong J, McCarthy T, MacLennan D. Measurement of resting cytosolic Ca2+ concentrations and $\mathrm{Ca} 2+$ store in HEK- 293 cells transfected with malignant hyperthermia or central core disease mutant $\mathrm{Ca} 2+$ release channels. J Biol Chem 1999;274:693-702.

42 Sambuughin N, Nelson T, Jankovic J, Xin C, Meissner G, Mullakandov M, Ji J, Rosenberg H, Sivakumar K, Goldfarb L. Identification and functional characterisation of a novel ryanodine receptor mutation causing malignant hyperthermia in North American and South American families. Neuromuscul Disord 2001;11:530-7.

43 Wehner M, Rueffert H, Koenig F, Neuhaus J, Olthoff D. Increased sensitivity to 4-chloro-m-cresol and caffeine in primary myotubes from malignant hyperthermia susceptible individuals carrying the ryanodine receptor 1 Thr2206Met (C6617T) mutation. Clin Genet 2002;62:135-46.

44 Girard T, Treves S, Censier K, Mueller C, Zorzato F, Urwyler A. Phenotyping malignant hyperthermia susceptibility by measuring halothane-induced changes in myoplasmic calcium concentration in cultured human skeletal muscle cells. Br J Anaesth 2002;89:571-9.

45 Robinson R, Brooks C, Brown S, Ellis R, Halsall J, Quinnel R, Shaw M-A Hopkins P. RYR 1 mutations causing central core disease are associated with more severe malignant hyperthermia in vitro contracture test phenotypes. Hum Mutat 2002;20:88-97.

46 Avila G, O'Connell K, Dirksen R. The pore region of the skeletal muscle ryanodine receptor is a primary locus for excitation-contraction uncoupling in central core disease. J Gen Physiol 2003;121:277-86.

47 Dirksen R, Avila G. Altered ryanodine receptor function in central core disease: leaky or uncoupled Ca2+ release channels? Trends Cardiovasc Med 2002; 12:189-97

48 Gao L, Balshaw D, Xu L, Tripathy A, Xin C, Meissner G. Evidence for a role of the luminal M3-M4 Loop in skeletal muscle Ca2+ release channel (ryanodine receptor) activity and conductance. Biophys J 2000;79:828-40. 